\title{
An Analysis of the Determinants of Arbitrage Spread
}

\section{Etienne Redor}

Audencia Business School, Nantes, France

Email: eredor@audencia.com

How to cite this paper: Redor, E. (2019) An Analysis of the Determinants of Arbitrage Spread. Theoretical Economics Letters, 9, 489-498.

https://doi.org/10.4236/tel.2019.93034

Received: October 30, 2018

Accepted: March 9, 2019

Published: March 12, 2019

Copyright $\odot 2019$ by author(s) and Scientific Research Publishing Inc. This work is licensed under the Creative Commons Attribution International License (CC BY 4.0).

http://creativecommons.org/licenses/by/4.0/

\begin{abstract}
This study examines the determinants of arbitrage spread of S\&P 500 firms between 2004 and 2014. We find that bid hostility, the relative size of the target compared to the potential bidder and the acquisition premium paid by the bidding firm are associated with greater arbitrage spread while the proportion of cash in the offer and target termination fees are associated with smaller arbitrage spread.
\end{abstract}

\section{Keywords}

Arbitrage Spread, Determinants, Mergers and Acquisitions

\section{Introduction}

Risk arbitrage is generally understood to be "trading around corporate events that alter the capital structure of a firm" [1]. The idea of risk arbitrage can be applied in the context of mergers and acquisitions ("merger arbitrage"), wherein the securities of a firm targeted for acquisition are acquired, and the arbitrager takes a long position in the target stock, hoping that the acquisition will go through.

Acquisition premiums are often used by bidding firms to encourage the target's shareholders to sell. On average, this premium is between $30 \%$ and $50 \%$ [2] which means that, in order to encourage current shareholders to sell their shares, the bidding firm offers a $30 \%$ to $50 \%$ premium over target's current stock price. In response, the target's stock price increases. As there is always a chance that the acquisition will not go through, investors seek to manage this completion risk while still benefitting from the increase in stock price.

Merger arbitragers help to manage this completion risk. They buy the shares from the target shareholders providing liquidity for the stock and bear the risk of 
deal completion. Since the number of investors and financial institutions that can buy the target's shares are limited [3] the target's stock typically trades at a discount to the price offered by the acquiring firm [4]. If the deal is successful, the arbitrage spread (the difference between the offer price and the target's stock price) is captured by the arbitragers as profit. On the contrary, if the deal fails, the stock price falls toward pre-announcement levels which results in significant losses for the arbitrageurs. The merger arbitrage strategy differs according to the payment method used to finance the merger and acquisition (M\&A). In a cash offer, the arbitrageur buys the target's stock and holds it until merger is consummated. Since the target's stock typically trades bellow the offer price, at the merger date, the arbitrageur pockets the arbitrage spread. In a stock swap or a mixed offer, the arbitrageur buys the target's stock and may sell short the acquiring firm's stock (to hedge market risk).

Most of the previous research on merger arbitrage has focused on the returns related to the merger arbitrage investment strategies. The main results of these studies can be summarized as follows: 1 ) merger arbitrage generates statistically and economically significant excess returns (see Table 1), 2) abnormal returns are higher for cash tender offers than for stock tender offers [5], 3) there is a substantial decline in the arbitrage spread as time passes [6]. Conversely, not much research has been done on the determinants or factors affecting arbitrage spread. Only one study of which we are aware documents that bid premium and

Table 1. Summary of studies documenting that merger arbitrage generates substantial excess returns.

\begin{tabular}{|c|c|c|}
\hline Study & Sample & Main results \\
\hline Bhagat et al. [9] & $\begin{array}{l}295 \text { cash tender offers between } \\
1962 \text { and } 1980 .\end{array}$ & $\begin{array}{l}\text { Average target excess return of } 2 \% \text { from } 2 \text { days } \\
\text { after the tender offer announcement to the day } \\
\text { prior to the expiration of the offer. }\end{array}$ \\
\hline $\begin{array}{l}\text { Larcker and Lys } \\
\qquad 10]\end{array}$ & $\begin{array}{l}111 \text { target stocks that were the } \\
\text { subject of SEC 13-D filings } \\
\text { between } 1977 \text { and } 1983 \text {. }\end{array}$ & $\begin{array}{l}\text { The mean (median) cumulative excess return is } \\
5.32 \%(2.56 \%) \text { from the time of investment to } \\
\text { the resolution of the offer. }\end{array}$ \\
\hline Dukes et al. [11] & $\begin{array}{l}761 \text { cash tender offers over the } \\
\text { period } 1971 \text { through } 1985 .\end{array}$ & Average daily returns of $0.47 \%$. \\
\hline $\begin{array}{l}\text { Karolyi and } \\
\text { Shannon [12] }\end{array}$ & $\begin{array}{l}37 \text { Canadian acquisition targets } \\
\text { valued at over } \$ 50 \text { million } \\
\text { during the year } 1997 \text {. }\end{array}$ & $\begin{array}{l}\text { The average return to the risk arbitrage strategy } \\
\text { yielded } 4.78 \% \text { in excess of the TSE } 300 \text { stock } \\
\text { index. }\end{array}$ \\
\hline $\begin{array}{l}\text { Mitchell and } \\
\text { Pulvino [4] }\end{array}$ & $\begin{array}{l}4750 \text { mergers and acquisitions } \\
\text { between } 1963 \text { and } 1998 .\end{array}$ & $\begin{array}{l}\text { Excess returns of } 4 \% \text { per year after taking into } \\
\text { account transaction costs. } \\
\text { The relation between risk arbitrage returns and } \\
\text { market returns varies with market conditions. }\end{array}$ \\
\hline $\begin{array}{c}\text { Baker and } \\
\text { Savasoglu [3] }\end{array}$ & $\begin{array}{l}1335 \text { pure cash and } 566 \text { pure } \\
\text { stock mergers and acquisitions } \\
\text { between } 1981 \text { and } 1996 .\end{array}$ & $\begin{array}{l}\text { Abnormal returns of } 0.6 \%-0.9 \% \text { per month on a } \\
\text { diversified portfolio of risk arbitrage positions. } \\
\text { Idiosyncratic risk and firm size are determinants } \\
\text { of expected returns. }\end{array}$ \\
\hline $\begin{array}{l}\text { Jindra and } \\
\text { Walking [7] }\end{array}$ & $\begin{array}{l}362 \text { cash tender offers between } \\
1981 \text { and } 1995 .\end{array}$ & $\begin{array}{l}\text { Abnormal monthly return of } 2 \% \text { for the target } \\
\text { from the day after the initial bid until bid } \\
\text { resolution. }\end{array}$ \\
\hline
\end{tabular}


bid hostility affect the size of the arbitrage spreads [7]. Importantly, Jindra and Walking's work focuses exclusively on cash tender offers. In this paper, we respond to the need expressed by Jindra and Walking for more research on the determinants of arbitrage spread by studying a large sample of M\&A's (not only cash tender offers) and by suggesting new determinants. According to some research, the arbitrage spread reflects the consensus view of how likely it is that the deal will be consummated [8]. In this study, we have used variables that have been identified as influencing the outcome of an M\&A as potential determinants of the merger spread, including the attitude of the bid, the size of the target, and the financing of the acquisition. We expect that a factor that positively impacts the probability of success of an M\&A will negatively impact the arbitrage spread. This paper proceeds as follows: Section 2 develops our hypotheses; Section 3 describes our data, the sample selection process, and the methodology; Section 4 shows the results; and section 5 provides our conclusions.

\section{Hypotheses Development}

Since the merger arbitrager is bearing the completion risk of the M\&A, it is imperative that he determines the likelihood of success of a M\&A [8]. There are four reasons M\&As fail: 1) intervention by the regulatory authorities, 2) successful defense by target management, 3) voluntary withdrawal on the bidder's part, and 4) rejection of the bid [13]. Since $90 \%$ of announced M\&A attempts are completed [14], certain factors may have an impact on the outcome of M\&As [15]. The purpose of this section is to summarize the literature which addresses how the success of a takeover can be predicted (Table 2) and to develop our hypotheses.

One of the most important factors influencing the success of an M\&A is whether the bid is viewed as friendly or hostile by the target company. Although distinguishing between hostile and friendly takeovers is not always simple [16], hostility to a bid is shown to have a negative impact on M\&A success [14] [17] [18] [19] [20]. In a UK sample, it was shown that a friendly offer has a $96 \%$ chance of success while a hostile offer has only a $61 \%$ chance of success [21]. This indicates that certain defensive strategies, such as enlisting a white knight, lobbying friendly shareholders, gathering the support of the unions, litigation [22], or having a poison pill, significantly improve the chances of a successful defense [23].

Hypothesis 1: Bid hostility has a positive impact on the arbitrage spread.

A second very important determinant of the success of an M\&A is the size of the target company (or, the relative size of the target compared to the potential bidder). The target's size influences the success of a M\&A negatively because large targets are costlier to acquire and tend to have more resources to defend themselves against hostile offers [17] [20].

Hypothesis 2: Target size has a positive impact on the arbitrage spread.

The method used to finance a deal (cash versus stock) is also decisive in determining the success of a bid [20] [14]. In a world of asymmetric information 
Table 2. Summary of studies analyzing the predictor of takeover success.

\begin{tabular}{|c|c|c|}
\hline Study & Sample & Main results \\
\hline $\begin{array}{l}\text { Hoffmeister and } \\
\text { Dyl [17] }\end{array}$ & $\begin{array}{l}84 \text { cash tender offers } \\
\text { during } 1976 \text { and } 1977\end{array}$ & $\begin{array}{l}\text { The multivariate discriminant analysis shows that the most decisive variables in determining success } \\
\text { are the attitude of the bid and the target size. The size of the bid premium has no impact. }\end{array}$ \\
\hline Walkling [18] & $\begin{array}{l}158 \text { cash tender offers } \\
\text { between } 1972 \text { and } 1977\end{array}$ & $\begin{array}{l}\text { The logistic regression shows that an increase in the bid premium, a toehold or the payment of } \\
\text { solicitation fees have a positive impact on the probability of success. Conversely, hostile offers and } \\
\text { the existence of a competing bid decreases the probability of success. }\end{array}$ \\
\hline $\begin{array}{l}\text { Holl and Kyriazis } \\
\quad[21]\end{array}$ & $\begin{array}{l}238 \text { M\&As that occurred } \\
\text { in the UK between } 1980 \\
\text { and } 1989\end{array}$ & $\begin{array}{l}\text { The logistic regression shows that the attitude of the bid and the wealth effect of a bid (whether } \\
\text { measured in terms of abnormal returns or bid premium) are key determinants of success. Large } \\
\text { toeholds have a positive impact on M\&A success. Moreover, the bid outcome is non-linearly related } \\
\text { to target director holdings. }\end{array}$ \\
\hline $\begin{array}{l}\text { Flanagan et al. } \\
\quad[19]\end{array}$ & $\begin{array}{l}991 \text { tender offers during } \\
\text { the period } 1985 \text { through } \\
1994\end{array}$ & $\begin{array}{l}\text { The logistic regression shows that: focusing M\&As (when the bidder and the target belong to the } \\
\text { same industry), cross-border M\&As, the existence of termination fee and bigger toeholds have a } \\
\text { significant, positive, effect on the M\&A outcome. Hostile offers and the existence of competing } \\
\text { bidders have a significant, negative, impact on the success of an attempted M\&A. The bid premium } \\
\text { and the target profitability were not significant determinant of the success of a M\&A. }\end{array}$ \\
\hline $\begin{array}{l}\text { Branch and Yang } \\
\quad[20]\end{array}$ & $\begin{array}{l}1097 \text { deals between } 1991 \\
\text { and } 2000\end{array}$ & $\begin{array}{l}\text { The multivariate prediction model shows that the most significant variables are the attitude of the } \\
\text { bid and the target relative size. While the debt ratio of the target has a significant positive effect on } \\
\text { the success of an attempted M\&A, the percentage of shares sought by the potential acquirer has a } \\
\text { negative effect. Cash offers are also more likely to succeed. Finally, the bid premium is not } \\
\text { significant in the prediction model. }\end{array}$ \\
\hline Branch et al. [14] & $\begin{array}{l}1196 \text { deals between } 1991 \\
\text { and } 2004\end{array}$ & $\begin{array}{l}\text { The empirical results show that the attitude of the bid, the arbitrage spread, the method of payment } \\
\text { and the percentage of shares sought by the potential acquirer are the most significant variables to } \\
\text { predict M\&A success. }\end{array}$ \\
\hline Betton et al. [23] & $\begin{array}{l}10,806 \text { control contests } \\
\text { over the period } \\
1973-2002\end{array}$ & $\begin{array}{l}\text { The probability that the target will be successfully acquired increases when the offer is a pure cash } \\
\text { offer, when the bidder has a toehold, when the bid is a tender offer and the bidder is a listed firm but } \\
\text { decreases when the target has a poison pill and if the offer is rejected by the target management. }\end{array}$ \\
\hline
\end{tabular}

[24] [25], the target and the bidder have private information on the value of their own enterprises. In other words, they know whether their stock is currently overvalued, undervalued or, fairly priced by the market. A bidder with overvalued stock might be inclined to use stock to reduce the effective cost of the acquisition. However, accepting a stock offer for a target will be riskier because it does not know the correct value of the bidder's stock and bears the risk of overvaluation. It is better for the target to accept a cash offer because the value of cashis certain. Therefore, cash offers are more likely to succeed than stock offers.

Hypothesis 3: Cash offers have a negative impact on the arbitrage spread.

The bid premium has also been identified as a predictor of takeover success [26] [27]. Although a higher bid premium could be attractive for the target shareholders and could facilitate the deal, the empirical evidence on the impact of bid premiums is unclear. Hoffmeister and Dyl [17], Flanagan et al. [19] and Branch and Yang [20] found little evidence to support the proposition that the size of the bid premium influences the M\&A outcome.

However, Walking [18] and Holl and Kyriazis [21] found that the bid premium has a positive impact on takeover success. Because of the mixed results, contradictory hypotheses can be made:

Hypothesis 4a: A higher premium has a negative impact on the arbitrage spread. 


\section{Hypothesis 4b: A higher premium has no impact on the arbitrage spread.}

The presence of termination fees in the M\&A agreement has also been shown to have a significant positive impact on the probability of M\&A success [28] [29]. A termination fee, also known as a break-up fee, is a penalty paid by one party to the other party in the event an M\&A agreement is terminated [30]. Since target termination fees, where the target agrees to pay a fee if the target abrogates the agreement, are more common than bidder termination fees [28] [31], we focus on target terminations fees. Following Jeon and Ligon [32], we propose that it is the size of the fee, rather than the mere existence of a fee, that impacts the outcome of an M\&A.

Hypothesis 5: Higher termination fees have a negative impact on the arbitrage spread.

\section{Sample and Data}

The data comes from the Eikon database. We compiled a dataset of M\&As announced between 2004 and 2014 by S\&P 500 firms. We choose the S\&P 500 Index because it measures the performance of large cap companies in the United States. We limited our sample to deals valued at over $\$ 100$ million and full acquisitions (where $100 \%$ of the target shares are sought). We thus eliminated non-significant deals and avoided biasing the results. Divestitures were also excluded.

Our final sample is made up of 285 M\&As. Our dependent variable is the arbitrage spread. We have five independent variables: the attitude of the bid, the relative size of the target, the percentage of cash used to finance the deal, the acquisition premium and the termination fees. We also include two control variables which have been found to have a significant effect on M\&A success in previous studies: target performance [17] and target leverage [16]. The variables are described in Table 3.

Table 4(a) and Table 4(b) provide the descriptive statistics and Table 5 presents the correlation matrix for the variables in our multivariate analyses. The correlation matrix highlights significant correlations between some of our dependent variables. Potential multicollinearity issues in the regression analyses were checked by calculating the individual variance inflation factors (VIF) and the mean VIF. VIF $>10$ usually indicates serious redundancy between predictor variables. Multicollinearity does not seem to cause problems in the multivariate analysis since for each regression, the mean VIF is close to 1 (see Table 6).

\section{Results}

Table 6 presents the results of the multivariate analyses. Overall, the results are consistent with our hypotheses. First, we document that bid hostility is associated with greater arbitrage spread which validates hypothesis 1 . Second, we show a positive relationship between the relative size of the target compared to the potential bidder and the arbitrage spread. This validates hypothesis 2 . Third, 
Table 3. Definition of variables.

\begin{tabular}{|c|c|}
\hline Variables & Definition \\
\hline \multirow{2}{*}{$\begin{array}{l}\text { Dependent variable: } \\
\quad \text { Spread }\end{array}$} & Value of transaction at announcement date/Number of target's share outstanding \\
\hline & Target closing price at announcement date -1 \\
\hline \multicolumn{2}{|l|}{ Independent variables: } \\
\hline Attitude of the bid & $\begin{array}{c}\text { Dummy variable that equals to " } 1 \text { " if the offer is a hostile offer, and " } 0 \text { " } \\
\text { otherwise. }\end{array}$ \\
\hline \multirow{2}{*}{ Relative size } & Value of transaction at announcement date \\
\hline & Market capitalisation of the bidder at announcement date \\
\hline Payment method & Percentage of cash offered by the bidder for the target. \\
\hline Premium & $\begin{array}{l}\text { Premium paid by the bidder based on the target's stock price one day } \\
\text { before the announcement. }\end{array}$ \\
\hline \multirow{2}{*}{ Termination fees } & Target termination fees \\
\hline & Value of transaction at announcement date \\
\hline \multicolumn{2}{|l|}{ Control variables: } \\
\hline Target performance & ROA $=\frac{\text { Net income }}{\text { Tits }}$ \\
\hline Target leverage & $\begin{array}{l}\text { Total assets } \\
\frac{\text { Total debt }}{\text { Total equity }}\end{array}$ \\
\hline
\end{tabular}

Table 4. (a) Descriptive statistics for continuous variables; (b) Descriptive statistics for the binary variable.

(a)

\begin{tabular}{cccccc}
\hline Variable & $\begin{array}{c}\text { Number of } \\
\text { observations }\end{array}$ & Mean & $\begin{array}{c}\text { Standard } \\
\text { deviation }\end{array}$ & Minimum & Maximum \\
\hline Spread & 285 & 0.215 & 0.296 & -0.204 & 2.001 \\
Relative size & 285 & 0.186 & 0.296 & 0.001 & 2.353 \\
Payment method & 280 & 0.726 & 0.381 & 0 & 1 \\
Premium & 284 & 0.335 & 0.278 & -0.177 & 2.389 \\
Termination fees & 264 & 0.031 & 0.008 & 0 & 0.071 \\
Target performance & 285 & 0.008 & 0.183 & -1.494 & 0.379 \\
Target leverage & 285 & 0.475 & 4.863 & -60.446 & 28.384 \\
\hline
\end{tabular}

(b)

\begin{tabular}{ccccc}
\hline & \multicolumn{2}{c}{$\mathbf{0}$} & \multicolumn{2}{c}{1} \\
\hline & $\mathrm{N}$ & $\%$ & $\mathbf{N}$ & $\%$ \\
\hline Attitude of the bid & 282 & 0.989 & 3 & 0.011 \\
\hline
\end{tabular}

Table 5. Correlation matrix.

\begin{tabular}{lcccccccc}
\hline & $\mathbf{1}$ & $\mathbf{2}$ & $\mathbf{3}$ & $\mathbf{4}$ & $\mathbf{5}$ & $\mathbf{6}$ & $\mathbf{7}$ & $\mathbf{8}$ \\
\hline 1-Spread & 1 & & & & & & & \\
2-Attitude of the bid & 0.290 & 1 & & & & & & \\
3-Relative size & 0.299 & 0.339 & 1 & & & & & \\
4-Payment method & -0.219 & -0.113 & -0.420 & 1 & & & & \\
\hline
\end{tabular}


Continued

\begin{tabular}{lcccccccc}
\hline 5-Premium & 0.202 & 0.084 & -0.081 & 0.148 & 1 & & & \\
6-Termination fees & -0.313 & -0.075 & -0.167 & 0.090 & 0.033 & 1 & & \\
7-Target performance & -0.069 & 0.046 & 0.185 & -0.085 & -0.342 & 0.016 & 1 & \\
8-Target leverage & 0.041 & -0.025 & -0.110 & -0.079 & -0.109 & -0.030 & 0.052 & 1 \\
\hline
\end{tabular}

Table 6. Analysis of the determinants of arbitrage spread.

\begin{tabular}{|c|c|c|c|c|c|c|c|}
\hline & Model 1 & Model 2 & Model 3 & Model 4 & Model 5 & Model 6 & Model 7 \\
\hline Constant & $\begin{array}{c}0.205^{* * *} \\
(0.000)\end{array}$ & $\begin{array}{c}0.151^{\star * *} \\
(0.000)\end{array}$ & $\begin{array}{c}0.345^{\star * *} \\
(0.000)\end{array}$ & $\begin{array}{c}0.170^{\star * *} \\
(0.000)\end{array}$ & $\begin{array}{c}0.554^{\star * *} \\
(0.000)\end{array}$ & $\begin{array}{c}0.519^{* * *} \\
(0.000)\end{array}$ & $\begin{array}{c}0.451^{* * *} \\
(0.000)\end{array}$ \\
\hline $\begin{array}{l}\text { Attitude } \\
\text { of the bid }\end{array}$ & $\begin{array}{c}0.805^{* * *} \\
(0.000)\end{array}$ & & & & & $\begin{array}{c}0.566^{* * *} \\
(0.001)\end{array}$ & $\begin{array}{c}0.495^{* * *} \\
(0.002)\end{array}$ \\
\hline Relative size & & $\begin{array}{c}0.337^{\star * *} \\
(0.000)\end{array}$ & & & & $\begin{array}{l}0.163^{\star *} \\
(0.012)\end{array}$ & $\begin{array}{c}0.165^{\star * *} \\
(0.009)\end{array}$ \\
\hline $\begin{array}{l}\text { Payment } \\
\text { method }\end{array}$ & & & $\begin{array}{c}-0.178^{\star * *} \\
(0.000)\end{array}$ & & & $\begin{array}{c}-0.083^{*} \\
(0.084)\end{array}$ & $\begin{array}{c}-0.103^{\star *} \\
(0.029)\end{array}$ \\
\hline Premium & & & & $\begin{array}{l}0.125^{\star} \\
(0.068)\end{array}$ & & & $\begin{array}{c}0.271^{\star * *} \\
(0.000)\end{array}$ \\
\hline $\begin{array}{c}\text { Termination } \\
\text { fees }\end{array}$ & & & & & $\begin{array}{c}-10.892^{\star * *} \\
(0.000)\end{array}$ & $\begin{array}{c}-8.979^{* * *} \\
(0.000)\end{array}$ & $\begin{array}{c}-9.194^{\star * *} \\
(0.000)\end{array}$ \\
\hline $\begin{array}{c}\text { Target } \\
\text { performance }\end{array}$ & $\begin{array}{l}-0.122 \\
(0.188)\end{array}$ & $\begin{array}{c}-0.208^{\star *} \\
(0.025)\end{array}$ & $\begin{array}{l}-0.132 \\
(0.165)\end{array}$ & $\begin{array}{l}-0.030 \\
(0.771)\end{array}$ & $\begin{array}{l}-0.105 \\
(0.258)\end{array}$ & $\begin{array}{c}-0.186^{\star *} \\
(0.039)\end{array}$ & $\begin{array}{l}-0.070 \\
(0.449)\end{array}$ \\
\hline $\begin{array}{l}\text { Target } \\
\text { leverage }\end{array}$ & $\begin{array}{l}0.006^{*} \\
(0.097)\end{array}$ & $\begin{array}{l}0.007^{\star *} \\
(0.047)\end{array}$ & $\begin{array}{c}0.004 \\
(0.305)\end{array}$ & $\begin{array}{c}0.006 \\
(0.119)\end{array}$ & $\begin{array}{c}0.002 \\
(0.552)\end{array}$ & $\begin{array}{c}0.003 \\
(0.337)\end{array}$ & $\begin{array}{c}0.004 \\
(0.195)\end{array}$ \\
\hline Observation & 285 & 285 & 280 & 284 & 264 & 259 & 258 \\
\hline $\mathbf{R}^{2}$ & 0.088 & 0.119 & 0.062 & 0.023 & 0.105 & 0.226 & 0.267 \\
\hline Mean VIF & 1 & 1.03 & 1.01 & 1.12 & 1 & 1.16 & 1.19 \\
\hline
\end{tabular}

p-values in parentheses: ${ }^{*} \mathrm{p}<0.10,{ }^{* *} \mathrm{p}<0.05,{ }^{* * *} \mathrm{p}<0.01$.

we observe a negative relationship between the proportion of cash in the offer and the arbitrage spread which is consistent with hypothesis 3 . Finally, hypothesis 5 is also verified since the results exhibit a negative relation between the size of target terminations fees and the arbitrage spread.

With respect to hypotheses $4 \mathrm{a}$ and $4 \mathrm{~b}$, we show that higher acquisition premium is associated to greater arbitrage spread. This result is somewhat counterintuitive since we would expect that the larger the acquisition premium, the greater the probability that an M\&A will be successful and thus the smaller the arbitrage spread. As evidenced by Hoffmeister and Dyl [17], Flanagan et al. [19] and Branch and Yang [20], the empirical relation between acquisition premium and the probability of M\&A success is not straightforward. Our results document a positive relation between the acquisition premium and the arbitrage spread. This could indicate that the bidder offers a higher premium when the merger outcome is uncertain in order to increase its chance of success. 


\section{Conclusions}

Studies analyzing the determinants of arbitrage spread are scarce. This paper contributes to this literature by studying the determinants of arbitrage spread of S\&P 500 firms between 2004 and 2014. The results show that bid hostility, the relative size of the target compared to the potential bidder and the acquisition premium paid by the bidding firm are associated with greater arbitrage spread while the proportion of cash in the offer and target termination fees are associated with smaller arbitrage spread.

This paper is one of the first attempts to identify the determinants of arbitrage spread. Other variables such as the existence of a toehold (a bidder's initial holding in the target firm) or the existence of competing offers may also be expected to be determinants of arbitrage spread since they have been shown to influence M\&A outcome. Unfortunately, our sample has not made it possible to test whether these variables are important determinants of arbitrage spread. Moreover, the use of complementary approaches (not only focused on the variables that are expected to influence M\&A outcomes) could allow finding other determinants of arbitrage spread. This might be a fruitful avenue for future research.

\section{Conflicts of Interest}

The author declares no conflicts of interest regarding the publication of this paper.

\section{References}

[1] Vidyamurthy, G. (2004) Pairs Trading: Quantitative Methods and Analysis. Wiley, New York.

[2] Laamanen, T. (2007) On the Role of Acquisition Premium in Acquisition Research. Strategic Management Journal, 28, 1359-1369. https://doi.org/10.1002/smj.639

[3] Baker, M. and Savasoglu, S. (2002) Limited Arbitrage in Mergers and Acquisitions. Journal of Financial Economics, 64, 91-115. https://doi.org/10.1002/smj.639

[4] Mitchell, M. and Pulvino, T. (2001) Characteristics of Risk and Return in Risk Arbitrage. Journal of Finance, 56, 2135-2175. https://doi.org/10.1111/0022-1082.00401

[5] Betton, S., Eckbo, B.E. and Thorburn, K.S. (2008) Corporate Takeovers. In: Eckbo, B.E., Ed., Handbook of Corporate Finance: Empirical Corporate Finance 2, North Holland, Amsterdam, 291-429. https://doi.org/10.1016/B978-0-444-53265-7.50007-X

[6] Jetley, G. and Ji, X. (2010) The Shrinking Merger Arbitrage Spread: Reasons and Implications. Financial Analysts Journal, 66, 1-15. https://doi.org/10.2469/faj.v66.n2.3

[7] Jindra, J. and Walkling, R.A. (2004) Speculation Spreads and the Market Pricing of Proposed Acquisitions. Journal of Corporate Finance, 10, 495-526. https://doi.org/10.1016/S0929-1199(03)00030-0

[8] Brown, K.C. and Raymond, M.V. (1986) Risk Arbitrage and the Prediction of Successful Corporate Takeovers. Financial Management, 15, 54-63. 
https://doi.org/10.2307/3664844

[9] Bhagat, S., Brickley, J.A. and Loewenstein, U. (1987) The Pricing Effects of Interfirm Cash Tender Offers. Journal of Finance, 42, 965-986. https://doi.org/10.1111/j.1540-6261.1987.tb03922.x

[10] Larcker, D.F. and Lys, T. (1987) An Empirical Analysis of the Incentives to Engage in Costly Information Acquisition: The Case of Risk Arbitrage. Journal of Financial Economics, 18, 111-126. https://doi.org/10.1016/0304-405X(87)90063-8

[11] Dukes, W.P., Frohlich, C.J. and Ma, C.K. (1992) Risk Arbitrage in Tender Offers. Journal of Portfolio Management, 18, 49-57. https://doi.org/10.1016/0304-405X(87)90063-8

[12] Karolyi, G.A. and Shannon, J. (1999) Where's the Risk in Risk Arbitrage? Canadian Investment Review, 12, 12-18.

[13] Wong, P. and O'Sullivan, N. (2001) The Determinants and Consequences of Abandoned Takeovers. Journal of Economic Surveys, 15, 145-186. https://doi.org/10.1111/1467-6419.00135

[14] Branch, B., Wang, J. and Yang, T. (2008) A Note on Takeover Success Prediction. International Review of Financial Analysis, 17, 1186-1193. https://doi.org/10.1016/j.irfa.2007.07.003

[15] Henry, D. (2004) Corporate Governance and Ownership Structure of Target Companies and the Outcome of Takeovers. Pacific-Basin Finance Journal, 12, 419-444. https://doi.org/10.1016/j.pacfin.2003.09.004

[16] Schwert, G.W. (2000) Hostility in Takeovers: In the Eyes of the Beholder? Journal of Finance, 55, 2599-2640. https://doi.org/10.1111/0022-1082.00301

[17] Hoffmeister, J.R. and Dyl, E.A. (1981) Predicting Outcomes of Cash Tender Offers. Financial Management, 10, 50-58. https://doi.org/10.2307/3664856

[18] Walkling, R.A. (1985) Predicting Tender Offer Success: A Logistic Analysis. Journal of Financial and Quantitative Analysis, 20, 461-478. https://doi.org/10.2307/2330762

[19] Flanagan, D.J., D’Mello, J.P. and O'Shaughnessy, K.C. (1998) Completing the Deal: Determinants of Successful Tender Offers. Journal of Applied Business Research, 14, 21-32. https://doi.org/10.19030/jabr.v14i3.5700

[20] Branch, B. and Yang, T. (2003) Predicting Successful Takeovers and Risk Arbitrage. Quarterly Journal of Business and Economics, 42, 3-18.

[21] Holl, P. and Kyriazis, D. (1996) The Determinants of Outcome in UK Take-Over Bids. International Journal of the Economics of Business, 3, 165-184. https://doi.org/10.1080/758528451

[22] Sudarsanam, P.S. (1995) The Role of Defensive Strategies and Ownership Structure of Target Firms: Evidence from UK Hostile Takeover Bids. European Financial Management, 1, 223-240. https://doi.org/10.1111/j.1468-036X.1995.tb00018.x

[23] Betton, S., Eckbo, B.E. and Thorburn, K.S. (2009) Merger Negotiations and the Toehold Puzzle. Journal of Financial Economics, 91, 158-178.

[24] Myers, S.C. and Majluf, N.S. (1984) Corporate Financing and Investment Decisions When Firms Have Information That Investors Do Not Have. Journal of Financial Economics, 13, 187-221. https://doi.org/10.1016/0304-405X(84)90023-0

[25] Hansen, R.G. (1987) A Theory for the Choice of Exchange Medium in Mergers and Acquisitions. Journal of Business, 60, 75-95. https://doi.org/10.1086/296386

[26] Fishman, M.J. (1988) A Theory of Preemptive Takeover Bidding. Rand Journal of Economics, 19, 88-101. https://doi.org/10.2307/2555399 
[27] Hirschleifer, D. and Titman, S. (1990) Share Tendering Strategies and the Success of Hostile Takeover Bids. Journal of Political Economy, 98, 295-324. https://doi.org/10.1086/261679

[28] Bates, T.W. and Lemmon, M.L. (2003) Breaking up Is Hard to Do? An analysis of Termination Fee Provisions and Merger Outcomes. Journal of Financial Economics, 69, 469-504. https://doi.org/10.1016/S0304-405X(03)00120-X

[29] Officer, M.S. (2003) Termination Fees in Mergers and Acquisitions. Journal of Financial Economics, 69, 431-467. https://doi.org/10.1016/S0304-405X(03)00119-3

[30] Butler, F.C. and Sauska, P. (2014) Mergers and Acquisitions: Terminations Fees and Acquisition Deal Completion. Journal of Managerial Issues, 26, 44-54.

[31] Bessler, W., Schneck, C. and Zimmermann, J. (2015) Bidder Contests in International Mergers and Acquisitions: The Impact of Toeholds, Preemptive Bidding, and Termination Fees. International Review of Financial Analysis, 42, 4-23. https://doi.org/10.1016/j.irfa.2015.04.004

[32] Jeon, J.Q. and Ligon, J.A. (2011) How Much Is Reasonable? The Size of Termination Fees in Mergers and Acquisitions. Journal of Corporate Finance, 17, 959-981.

https://doi.org/10.1016/j.jcorpfin.2011.04.013 